\title{
Chloroquine Ameliorates Adriamycin-Induced Testicular Damage by Suppressing the Inflammation and Apoptosis in Rats: A Histological, Immunohistochemical and Biochemical Study
}

\author{
La Cloroquina Mejora el Daño Testicular Inducido por la Adriamicina al Suprimir la \\ Inflamación y la Apoptosis en Ratas: Un Estudio Histológico, Inmunohistoquímico y Bioquímico
}

Ali Tugrul Akin; Emin Kaymak²; Emel Öztürk³ ${ }^{3}$ Derya Karabulut ${ }^{4}$ \& Ayse Toluk ${ }^{1}$

\begin{abstract}
AKIN, A. T.; KAYMAK, E.; ÖZTÜRK, E.; KARABULUT, D. \& TOLUK, A. Chloroquine ameliorates adriamycin-induced testicular damage by suppressing the inflammation and apoptosis in rats: A histological, immunohistochemical and biochemical study. Int. J. Morphol., 39(4):1123-1131, 2021.
\end{abstract}

SUMMARY: Adriamycin (ADR) is an anthracycline antibiotic used for treatment of many types of cancer. However, its applications may damage to healthy tissues. Chloroquine (CLQ) is an anti-inflammatory agent used in treatment of many inflammation associated diseases such as malaria and rheumatoid arthritis. Moreover, it is used in the treatment of pneumonia caused by COVID-19. The aim of this study is to determine possible therapeutic effects of Chloroquine on Adriamycin-induced testicular toxicity in rats. We investigated the effect of CLQ on testicular injury caused by ADR. Rats were divided into four groups: Control, ADR, CLQ, ADR+CLQ. After administrations, animals were sacrificed, and testis tissues were extracted from the animals for the further examinations. Histopathological changes in testis tissues were evaluated and TNF- $\alpha$ and IL-6 immunostaining were performed to determine the expression levels of these cytokines. TUNEL method were used for evaluation of apoptotic index. Moreover, serum testosterone levels were measured by ELISA assay. We observed that ADR group showed histopathological deterioration when compared to the Control group and CLQ treatment ameliorated this damage induced by Adriamycin.An increase in TNF- $\alpha$ and IL-6 immunoreactivities and in the number of apoptotic cells and a decrease in serum testosterone levels were determined in the ADR group compared to the Control and CLQ group. Furthermore, our examinations showed an improvement in testicular tissue in ADR+CLQ group in terms of these parameters when compared to the ADR group. We suggest that CLQ can be used as a protective agent to reduce the toxic effects of Adriamycin as a result of its antiinflammatory and anti-apoptotic properties.

KEY WORDS: Chemotherapy; Testis damage; TUNEL; IL-6; TNF-a.

\section{INTRODUCTION}

Cancer is widely known as a lethal disease characterized by uncontrolled cell proliferation and division under the control of several genetic and environmental factors (Howlader et al., 2019). In recent years, the increasing success rate of cancer treatment has provided long-term survival to patients and improved their life quality. However, this cytotoxic chemotherapeutics may cause a serious damage in healthy organs because their mechanism of action could not be completely understood (Patel \& Kaufmann, 2012). Chemotherapeutics have several side effects and gonadotoxicity is one of the most commonly known side effects of them (Lampe et al., 1997).
Adriamycin (ADR) is an antineoplastic agent used for the treatment of both solid tumors and several types of carcinomas such as lymphoma, bladder and breast cancer. Although it has wide usage, ADR is known to cause dosedependent toxicity for many organs in the body including testis (Malekinejad et al., 2012; Ahmed et al., 2013). The mechanism of ADR toxicity is referred to as two major theories. One of them suggests that ADR intercalates with DNA strands and inhibits the maintenance of the topoisomerase II enzyme and finally suppresses the replication and transcription of DNA. Another theory is that ADR causes damage in healthy tissues by inducing oxidative stress and drives the cell to apoptosis.

\footnotetext{
${ }^{1}$ Erciyes University, Science Faculty, Department of Biology, Kayseri, Turkey.

${ }^{2}$ Yozgat Bozok University, Faculty of Medicine, Histology-Embryology Department, Yozgat, Turkey.

${ }^{3}$ Harran University, Faculty of Medicine, Histology-Embryology Department, Sanliurfa, Turkey.

${ }^{4}$ Erciyes University, Faculty of Medicine, Histology-Embryology Department, Kayseri, Turkey.
} 
AKIN, A. T.; KAYMAK, E.; ÖZTÜRK, E.; KARABULUT, D. \& TOLUK, A. Chloroquine ameliorates adriamycin-induced testicular damage by suppressing the inflammation and apoptosis in rats: A histological, immunohistochemical and biochemical study. Int. J. Morphol., 39(4):1123-1131, 2021.

(Fimognari et al., 2008). Excessive formation of reactive oxygen species (ROS), the enervation of the antioxidant defense system and lipid peroxidation of bio-membranes may cause the upregulation of inflammatory pathways and excessive releasing of pro- and anti-inflammatory cytokines such as Tumor Necrose Factor-alpha (TNF- $\alpha$ ) and Interleukin6 (IL-6). Finally, disequilibrium between these cytokines may induce necrosis and apoptosis. Cytokines, which are polypeptides produced and secreted by various cell types, regulate immune and inflammatory events, including systemic response to inflammation, cell growth, healing and injury (Noronha et al., 1995). Several studies have demonstrated that ADR activates inflammatory pathways by causing the upregulation of inflammatory cytokines such as TNF- $\alpha$ and interleukins and triggers apoptosis in many tissue types (Zhang et al., 2019; He et al., 2020). These pathogenic patterns are considered as characteristics of male infertility induced by ADR (Rizk et al., 2014).

Chloroquine (CLQ) is a drug used as an antiinflammatory (Ben-Zvi et al., 2012) and it is commonly use in treatment of many inflammation associated diseases such as malaria (Lalloo et al., 2007) and rheumatoid arthritis (Rainsford et al., 2015). Moreover, it is recently used for the treatment of the pneumonia caused by Covid-19 (Huang et al., 2020). The effect of TNF- $\alpha$ inducing the upregulation of the other interleukins is prevented by the lysosomal protease inhibitor chloroquine (Lehmann et al., 2008). CLQ treatment could improve mortality in mice by inhibiting inflammatory pathways and death (Yang et al., 2013).

The aim of this study is to investigate the protective effects of Chloroquine in the testis of rats administered ADR. For this purpose, we evaluated the histopathological changes in testis and changes in the expressions of TNF- $\alpha$ and IL- 6 as a tissue inflammatory mediator. Moreover, we determined the apoptotic index in testicular tissue and measured the serum testosterone levels to determine the effects of ADR on male infertility in testis.

\section{MATERIAL AND METHOD}

Compliance with ethical standards. The experimental protocol performed in the present study was accepted by the Erciyes University's Experimental Animal and Local Ethics' Committee with number 19/205/2019. The authors declare that they have no conflict of interest and received no funding for this project.

Experimental design. In the present study, 32 male Wistar albino rats ( 8 weeks old, weighing 100-200 g) were obtained from Hakan Cetinsaya Experimental and Clinic Research Center, Erciyes University, Kayseri, Turkey. During the experiment, rats were harbored in a $12 \mathrm{~h}$ light $/ 12 \mathrm{~h}$ dark cycle at room temperature $\left(20-24^{\circ} \mathrm{C}\right)$ and environmental humidity. Standard chow and tap water were given to animals ad libitum. At the beginning of the experiment, the rats randomly divided into four groups as follows; The Control group $(n=8)$ were untreated rats, ADR $(\mathrm{n}=8)$ group administered $2 \mathrm{mg} / \mathrm{kg}$ Adriamycin intraperitoneally (i.p) one in three days for 30 days similar to literature (Shivakumar et al., 2012), CLQ group $(\mathrm{n}=8)$ group given $50 \mathrm{mg} / \mathrm{kg}$ Chloroquine for 30 days (Long et al., 2013) and ADR plus CLQ group $(\mathrm{n}=8)$ given $2 \mathrm{mg} / \mathrm{kg}$ Adriamycin one in three days and $50 \mathrm{mg} / \mathrm{kg}$ Chloroquine for 30 days. At the end of the experiment, animals were anesthetized with ketamine and xylazine combination and they were sacrificed after blood samples were collected for serum isolation. Collected serum samples were centrifuged for 10 $\mathrm{min}$ at $3000 \mathrm{rpm}$. After sacrifice, testis tissues were extracted from the animals for the histopathological, immunohistochemical examinations. Serum samples were kept at $-80{ }^{\circ} \mathrm{C}$ for later biochemical assays.

Histopathological examinations. Histopathological evaluation of the structure of the testicular tissue was performed using routine histological meth-ods. Testis tissues were fixed in $10 \%$ formalin solution for $24-48 \mathrm{~h}$, dehydrated with alcohol, cleared with xylene and embedded in paraffin wax and cut into $5 \mu \mathrm{m}$ thick sections. Hematoxylin-eosin (H\&E) staining were performed for the evaluation of the histopathological changes in tissue samples. Photographs were taken with a photomicroscope (Olympus BX51; Olympus, Tokyo, Ja-pan) and analyzed by the study group. Testicular tissue structure was examined and evaluated randomly with standard light microscopy by the study group. Seminiferous tubule diameters (MSTD) were measured in $\mu \mathrm{m}$ (Analysis LS Research Program). More than 20 seminiferous tubular sections were chosen for per testis and their histopathological score was evaluated with Johnsen's Testicular Biopsy Score (JTBS) from 1 to 10 as described previously (Johnsen, 1970).

Immunohistochemistry. The Immunohistochemistry method was applied according to previous studies (Bayatli et al., 2013) to investigate the changes in the immunoreactivities of TNF$\alpha$ and IL- 6 antibodies in testis tissues. Sections of $5 \mu \mathrm{m}$ were obtained from testis tissues embedded in paraffin blocks. The sections were kept in the oven at $60^{\circ} \mathrm{C}$ for at least 2 hours so that the paraffin melted. The tissues were deparaffinized and rehydrated using xylene and alcohol series. Sections were taken into a sterile urine container with $0.01 \mathrm{M}$ citrate buffer and heated in a microwave oven at $350 \mathrm{~W}$ for the antigen retrieval. Then, sections were kept three times in phosphate-buffered saline (PBS) for 5 minutes. The sections were kept in $3 \%$ 
(w/v) $\mathrm{H} 2 \mathrm{O} 2$ for 10 minutes to block endogenous peroxidase activity. After washing again 3 times in PBS, Ultra V Block solution was added to the tissues and kept in the tank for 5 minutes. After then, TNF-5 $\alpha$ (Cat. No: E-AB-52065, Elapscience, USA) and IL-6 (Cat. No: E-AB-40073, Elapscience, USA) antibodies diluted in the ratio of $1: 100$ were added to the tissues and incubated overnight at $4{ }^{\circ} \mathrm{C}$. The following morning, the tissues were washed again three times with PBS and the secondary antibody (TA-125-HDX, Thermo Fisher Scientific, Waltham, MA, USA) was instilled for 10 minutes at room temperature. After washing with PBS, the immunoreaction was amplified using the streptavidinavidin-peroxidase complex and the sections were visualized using 3,3-p-diaminobenzidine tetrahydrochloride (TA-060HDX, Thermo Fisher Scientific, Waltham, MA, USA) lightly counter-stained with Gill hematoxylin. For the final step, increasing alcohol serial concentrations were used to remove water, the sections were then passed through xylene, and finally, they were covered with entellan. Images were taken using a light microscope. Image J (1.45s, National Institute of Health, USA, RRID: SCR_003070) program was used to measure the density of immunoreactivities.

Terminal deoxynucleotidyl transferase-mediated d-UTP Nick End Labeling (TUNEL) assay. To determine the apoptotic index in testicular tissue, TUNEL assay was performed according to the kit procedure (Roche, In Situ Cell Death Detection Kit). Sections of $5 \mu \mathrm{m}$ were left in a $60{ }^{\circ} \mathrm{C}$ oven for at least 2 hours to melt paraffin. The tissues were deparaffinized and rehydrated using xylene and alcohol series. Sections were kept three times in phosphate buffered saline (PBS) for 5 minutes. Sections were taken into sterile urine container with $0.01 \mathrm{M}$ citrate buffer and heated in microwave oven at $350 \mathrm{~W}$, consequently antigen retrieval was obtained. Then, sections were kept three times in PBS for 5 minutes. $450 \mu \mathrm{L}$ of the purple-capped label solution and the blue-capped enzyme solution were mixed. We used this mixture for positives. We used $50 \mu \mathrm{L}$ of solution remaining in the label solution for negatives. These solutions are added to the tissues in the dark and then incubated in a $37^{\circ} \mathrm{C}$ oven for 1 hour. After washing with PBS, it is covered with dapi in the dark and TUNEL positive cells were calculated using fluorescent microscope.
Enzyme-Linked Immunosorbent (ELISA)assay. Rat Testosterone ELISA Kit (Cat. No: 201-11-5126, Sunredbio, China) was performed to detect the serum testosterone level. We centrifuged blood samples obtained from rats at 10000 rpm at $4{ }^{\circ} \mathrm{C}$ for 15 minutes. $150 \mu \mathrm{L}$ of the supernatant was taken into Eppendorf tubes separately for each group. In standard preparation, standard diluents was added to 5 tubes. Then $120 \mu \mathrm{L}$ of standard solution were added to the first tube and mixed. After then, $120 \mu \mathrm{L}$ from the previous tube was added to the other 4 tubes respectively. $40 \mu \mathrm{L}$ of supernatant was added to the samples section. Then, we added $10 \mu \mathrm{l}$ of testosterone antibody to the samples and incubated at $37{ }^{\circ} \mathrm{C}$ for 60 minutes. We added $50 \mu \mathrm{L}$ of streptavidin HRP to both samples and standard section and incubated for 10 minutes at $37^{\circ} \mathrm{C}$ then, solution $\mathrm{A}, \mathrm{B}$ and stop solution were added respectively and measured by ELISA reader.

Statistical analysis. All statistical analyses were carried out by using GraphPad Prism version 7.00 for Mac, GraphPad Software, La Jolla, California, USA. D'Agostino Pearson omnibus test was used to identify the normal distribution of the data. In the case of normal distribution, quantitative variables were compared using one-way analysis of variance (ANOVA) and Tukey's post hoc test. Kruskal Wallis and Tukey's post-hoc tests were used for comparing the quantitative with the abnormal distribution. The data were expressed as the mean of normalized data \pm standard deviation of the mean. $\mathrm{p}<0.05$ was considered as statistically significant.

\section{RESULTS}

Chloroquine ameliorated testicular damage induced by Adriamycin. Body weight in the ADR group decreased significantly compared to the Control group $(\mathrm{p}<0.005)$. Testis weight in the ADR group decreased significantly compared to the Control group. Body weight and testis weight in ADR + CLQ group were significantly higher compared to those of the ADR group ( $<<0.05)$ (Table I). In the ADR group, MSTD decreased significantly compared to the Control

Table I Body weights, testes weights, MSTD and JTBS in experimental groups.

\begin{tabular}{|c|c|c|c|c|c|c|}
\hline Groups & & Control & $\mathrm{ADR}$ & CLQ & $\mathrm{ADR}+\mathrm{CLQ}$ & $p$ \\
\hline \multirow{2}{*}{ Body weight (gr) } & Initial weight & $133 \pm 10.2$ & $211.1 \pm 9.4$ & $128.3 \pm 15.6$ & $166.5 \pm 14.5$ & 0.001 \\
\hline & Final weight & $270.3 \pm 19.8$ & $137.7 \pm 13.7$ & $223.7 \pm 45.8$ & $176.6 \pm 20.4$ & 0.001 \\
\hline Testes weight (gr) & & $1.45 \pm 0.10$ & $0.98 \pm 0.12^{*}$ & $1.49 \pm 0.22$ & $1.11 \pm 0.09^{\#}$ & 0.001 \\
\hline JTBS (1 to 10$)$ & & $9.44 \pm 0.66$ & $7.01 \pm 1.02^{*}$ & $9.50 \pm 0.68$ & $9.13 \pm 0.82^{\#}$ & 0.001 \\
\hline $\operatorname{MSTD}(\mu \mathrm{m})$ & & $290.8 \pm 42.0$ & $229.5 \pm 40.9^{*}$ & $302.7 \pm 34.9$ & $282.5 \pm 42.1^{\#}$ & 0.001 \\
\hline
\end{tabular}

Data are expressed as mean \pm standard deviation and $\mathrm{p}<0.05$ was considered as significant. * Significant when compared to Control and CLQ group. \# Significant when compared to ADR group. 
group ( $\mathrm{p}<0.05)$. JTBS in the ADR group decreased substantially compared to the Control group $(\mathrm{p}<0.05)$ while a significant increase in JTBS was observed in the ADR + CLQ group compared to the ADR group ( $\mathrm{p}<0.05)$. In other words, CLQ administration to ADR-treated rats provided improvement in testicular histological view when compared to the ADR group (Fig. 1D). A decline in germinal cells, disorganization in the seminiferous tubule basal membrane and seminiferous epithelium, vacuolization and immature germinal epithelial cells in the lumen were seen in the ADR group (Fig. 1C). In the ADR+CLQ group, although there were a few tubules in which non-matured germinal epithelial cells were seen in the lumen, the appearance was close to that of the Control and CLQ group (Fig. 1D).
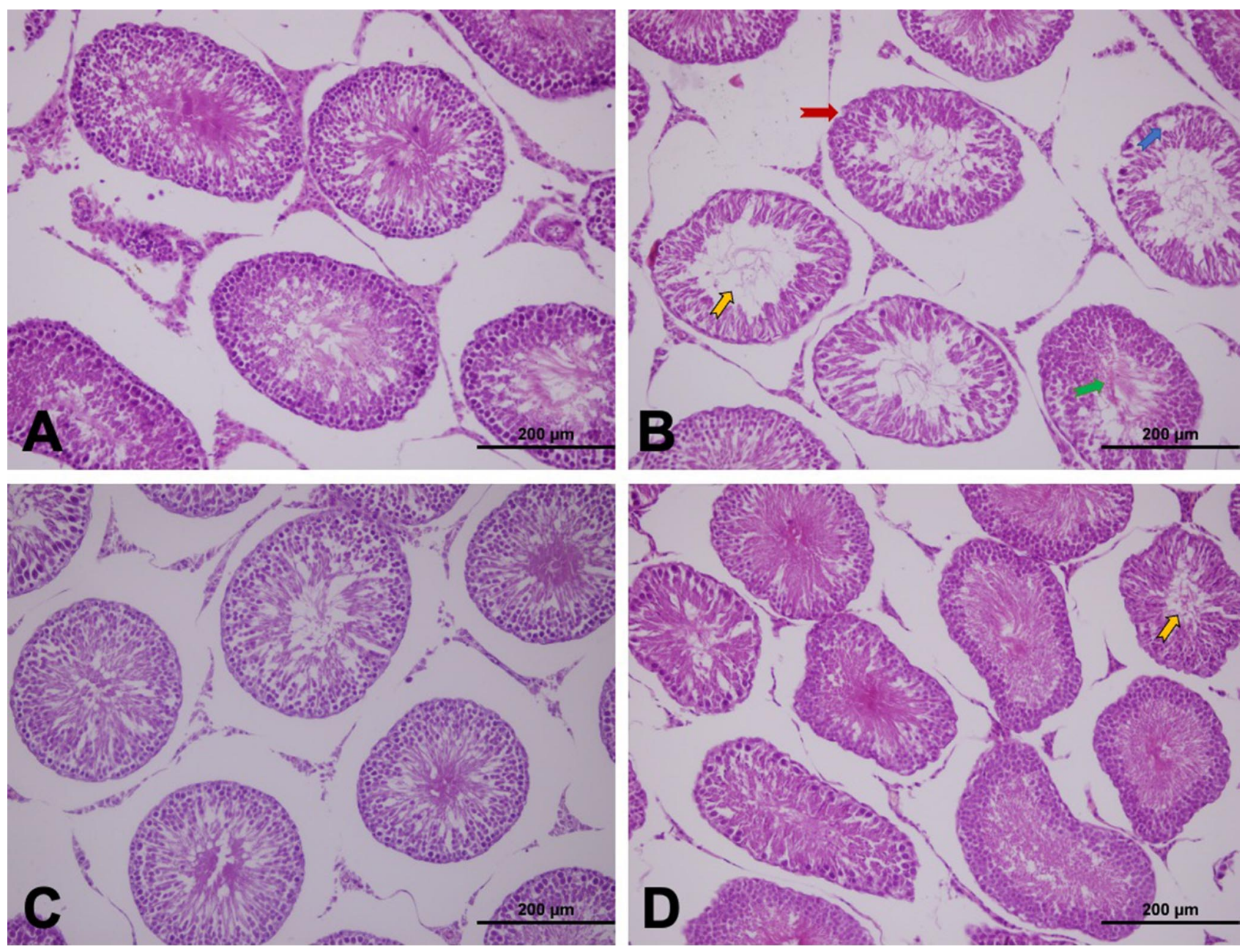

Fig. 1. A-D. Light microscopy of testicular tissue stained with H\&E in experimental groups. (A) Control group ( $\mathrm{n}=8$ ), normal testes were observed; (B) ADR group ( $\mathrm{n}=8$ ), disorder of seminiferous tubule basal membrane and germinal epithelium (red arrow), desquamation of epithelial cells (yellow arrow), vacuolization (blue arrow)and immature germinal cells (green arrow) in the lumen were observed; (C) CLQ group ( $n=8)$ and (D) ADR+CLQ group, normal testicular architecture were observed; Scala bar: 200 m. Abbreviations: ADR, Adriamycin; CLQ, Chloroquine; H\&E, Hematoxylin and eosin.

Increased TNF-a and IL-6 levels decreased by chloroquine. Immunohistochemical staining was performed by using the avidin-biotin method to determine the testes tissue expressions of TNF- $\alpha$ and IL-6. Immunohistochemical examinations demonstrated the presence of TNF- $\alpha$ and IL6 immunoreactivity in the germinal cells of the seminiferous tubules. The TNF- $\alpha$ and IL- 6 expressions in the testes of
CLQ group were similar to those in the control group. Especially, TNF- $\alpha$ and IL-6 immunoreactivity were considerably increased in germinal cells in ADR group. TNF$\alpha$ and IL-6 expressions of ADR+CLQ were substantially less compared to those in the ADR group. Figure 2 shows the TNF- $\alpha$ and IL- 6 expressions and statistical analysis in experimental groups. 

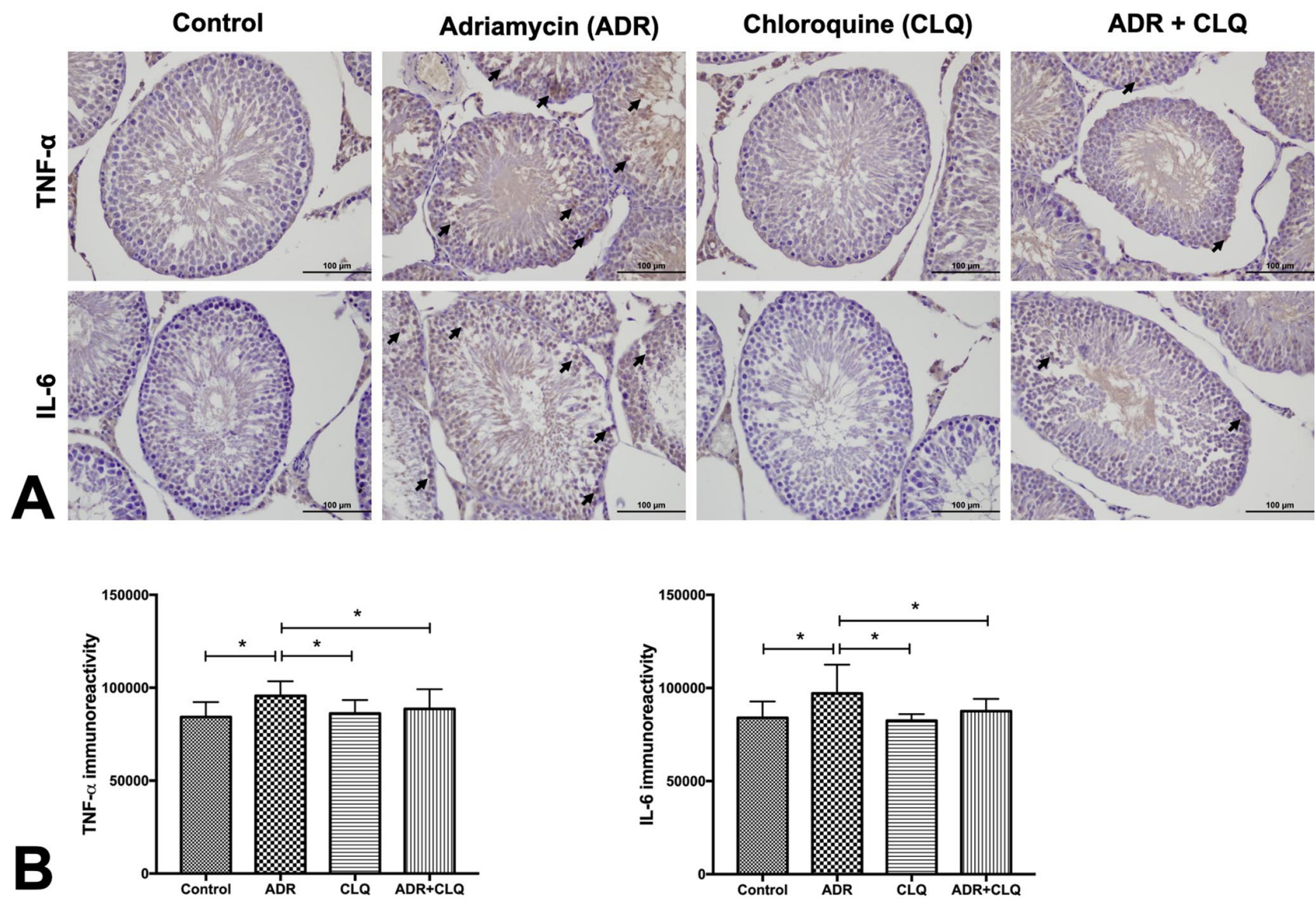

Fig. 2. (A) Immunohistochemical staining of TNF- $\alpha$ and IL-6 in testicular tissues and (B) statistical analysis of the expression levels in experimental groups. Control $(n=8)$ and CLQ $(n=8)$ showed weak TNF- $\alpha$ immunostaining in germinal cells in the seminiferous tubules; ADR ( $n=8)$ group, TNF-a expression increased in the germ cells of seminiferous tubules. ADR+CLQ ( $n=8)$ TNF- $\alpha$ expression was significantly decreased when compared to the ADR group. Similarly, weak IL-6 immunostaining was observed in germinal cells in the seminiferous tubules of Control $(n=8)$ and CLQ $(n=8)$;ADR $(n=8)$ group, IL-6 expression increased in the germ cells of seminiferous tubules. ADR+CLQ ( $n=8)$ IL-6 expression was significantly less when compared to the ADR group. Black arrows show the immunoreactive cells. Abbreviations: ADR, Adriamycin; CLQ, Chloroquine; TNF- $\alpha$, Tumor Necrose Factor alpha; IL-6, Interleukin 6.

Table II Changes in serum testosterone levels and apoptotic cell number among experimental groups.

\begin{tabular}{lcccc}
\hline Groups & Control & ADR & CLQ & ADR+CLQ \\
\hline Plasma Testosterone Level $(\mathrm{pg} / \mathrm{ul})$ & $405.9 \pm 97.09$ & $367.6 \pm 61.67$ & $402.9 \pm 44.02$ & $401.6 \pm 73.94$ \\
Number of Apoptotic Cells & $0.26 \pm 0.77$ & $0.92 \pm 1.32 *$ & $0.24 \pm 0.43$ & $0.26 \pm 0.44 \#$
\end{tabular}

All data are expressed as the mean \pm SD $(n=8) . p<0.05$ was considered as significant. * Significant when compared to Control and CLQ group. \# Significant when compared to ADR group.

Reduced testicular apoptosis by chloroquine. TUNEL staining was performed to determine apoptotic cells in testes tissue (Fig. 3). Number of apoptotic cells among experimental groups was expressed as median (min-max) and statistical analysis of them were given in Table II and Figure 3. The apoptotic cells in the testis of Control group and CLQ group were found $0(0-4)$ and $0(0-1)$ respectively and there was not statistically significance between them. The increase in the apoptotic cell number in ADR group was found $0(0-5)$ and was statistically significant when compared to Control group ( $\mathrm{p}<0.001)$. In the ADR+CLQ group, there was a decrease in TUNEL-positive cells and the apoptotic cell number 0 (0$1)$. The decrease in the apoptotic cell number was statistically different in ADR+CLQ when compared to ADR group $(\mathrm{p}<0.05)$. 
A

Control

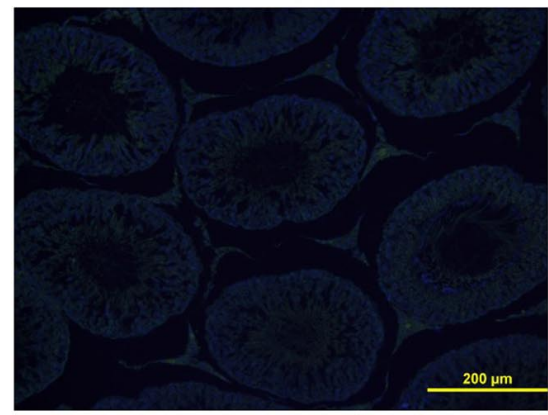

Chloroquine (CLQ)
Adriamycin (ADR)

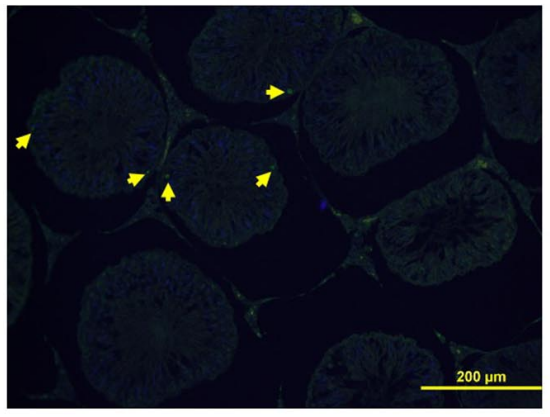

$A D R+C L Q$
B

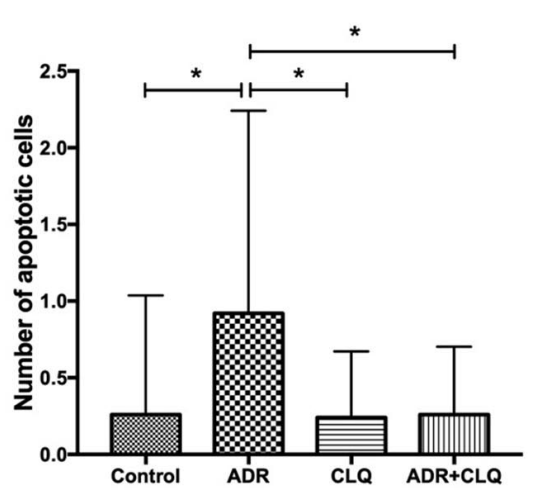

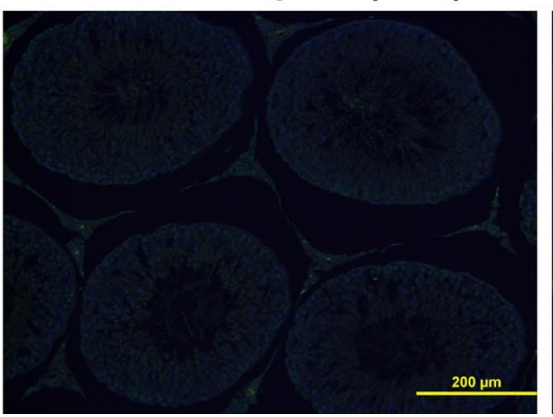

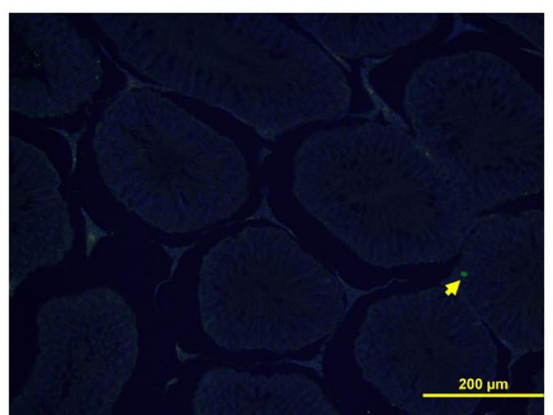

Fig. 3. (A) TUNEL staining of testicular tissue and (B) statistical analysis of number of apoptotic cells. Control $(n=8)$ and CLQ $(n=8)$ groups, normal testes were observed; ADR $(n=8)$ group, TUNEL-positive cells were mainly observed in germ cells of testis. ADR+CLQ $(\mathrm{n}=8)$ decrease in TUNEL-positive cells was observed. Yellow arrows show the apoptotic cells. Abbreviations: ADR, Adriamycin; CLQ, Chloroquine; TUNEL, Terminal deoxynucleotidyl transferase-mediated d-UTP Nick End Labeling.

Decreased serum testosterone levels enhanced by chloroquine. Exposure of Adriamycin substantially decreased the serum testosterone levels in comparison with the Control group (Table II), suggesting the inhibitory role of ADR on testicular androgenesis. Serum testosterone levels decreased in ADR when compared to the Control group, but this decrease in serum testosterone levels was not significant $(p>0.05)$. However, the serum testosterone level of ADR+CLQ was higher than ADR group. Although serum testosterone level in the ADR+CLQ group was higher than the ADR group ( $p>0.05$ ) (Table II), there was no statistically significant difference between these groups.

\section{DISCUSSION}

In spite of Adriamycin's potent antineoplastic activity in many types of cancer, its clinical use has detrimental side effects in many healthy organs. Many studies have reported that ADR causes a substantial decrease in reproductive organ weights and deterioration in their structure (Imahie et al.,
1995; Yeh et al., 2009). In the present study we observed a significant decrease in the body weight and testicular weight of ADR-administered animals. We suggest that this decrease may be due to the detrimental effects of Adriamycin and parenchymal atrophy in the seminiferous tubules and spermatogenic devastation in testicular tissue. Studies on the effects of ADR treatment showed that ADR treatment causes a significant decrease in the diameters of the seminiferous tubule, degeneration of spermatocytes, spermatogonia and seminiferous tubules, decreased seminiferous epithelial layers, less number of germ cells (Turedi et al., 2015). Our study showed that ADR led to a decrease in MSTD, reduction in germinal cells, disorganization in the seminiferous tubule basal membrane and seminiferous epithelium, vacuolization and immature germinal epithelial cells in the lumen similar to literature.

Cytokines are polypeptides produced and secreted by various cell types and they regulate the immune and inflammatory events, including systemic response to inflammation and apoptosis. Many studies have reported that in many types of tissues the expression of inflammatory 
cytokines such as TNF- $\alpha$ and IL-6 is increased when inflammation is triggered (Zhang et al.; He et al.). In this study, we observed that the immunoreactivities of TNF$\alpha$ and IL- 6 increased in testicular tissues of ADR administered rats. Our immunohistochemical results showed that ADR administrations caused a significant inflammation by inducing the upregulation of inflammatory cytokines such as TNF- $\alpha$ and IL-6. On the contrary, CLQ treatment caused a significant decrease in the expression levels of TNF- $\alpha$ and IL- 6 . According to our statistical analysis of immunoreactivity measurements, there was no statistically significant difference among Control, CLQ and ADR plus CLQ group in terms of the expression levels of TNF- $\alpha$ and IL6. In light of these results, we suggest that CLQ therapy against testicular damage induced by ADR causes significant improvement by suppressing inflammatory pathways, including TNF- $\alpha$ and IL-6, through its antiinflammatory properties.

Adriamycin induces two major apoptotic signaling pathways, the mitochondrial pathway and death receptor pathway which are closely related to inflammatory pathways characterized by the upregulation of Nuclear Factor kappa-B (NF-kB). However, recent studies have reported that the mitochondrial pathway is the major signaling pathway activated in ADR-induced toxicity (Elsharkawy \& Mann, 2007; Ryter et al., 2007; Xiao et al., 2012). There are several studies suggesting that Adriamycin administration triggered apoptosis in testicular tissue in rats (Fouad et al., 2019). In the present study, our TUNEL assay result showed that the number of apoptotic cells both in the seminiferous tubules and interstitial region significantly increased in testicular tissue of Adriamycin administered rats. Moreover, in ADR plus CLQ group the number of apoptotic cells was similar to the Control and CLQ group and there was no significant difference among these groups. Although, some studies have reported that CLQ treatment increase the apoptosis by deranging the balance between autophagy and apoptosis (Wang et al., 2020), there are also other studies suggesting that low doses of CLQ protect retinal ganglion cells from apoptosis by attenuating ROS level (Ma et al., 2019). Our results suggest that CLQ treatment decreased the apoptotic cell number by suppressing apoptotic pathways triggered by inflammation. Furthermore, many studies have suggested that ADR administration decrease the serum or tissue testosterone levels in rats because of apoptosis in interstitial cells (Leydig cells) that release androgens in the presence of the luteinizing hormone ( $\mathrm{LH})$ necessary for spermatogenesis in interstitial region (Fouad et al.). Our biochemical results obtained by ELISA assay showed that the serum testosterone levels in ADR administered rats decreased when compared to Control group. Moreover, we observed an increased serum testosterone levels in the ADR plus CLQ group when compared to ADR group, but this increase was not statistically significant. We think this insignificance is due to the low number of samples. According to our biochemical results indicating the tendency towards decreased serum testosterone levels, we suggest that CLQ treatment has a potentially positive effect on serum testosterone levels in the testicular damage induced by Adriamycin.

There are some clinical and experimental reports suggested that CLQ treatment causes ocular toxicity including keratopathy, ciliary body involvement, lens opacities, and retinopathy and retinopathy is the major concern (Yam \& Kwok, 2006; Yamagiwa et al., 2019). On the contrary, other studies have suggested that low doses of CLQ administrations protect retinal ganglion cells by attenuating ROS levels and modulating apoptosis induced by glutamate (Ma et al.). Moreover, some studies performed on experimental rat models and presented as case reports have reported that high doses of CLQ treatment induce cardiac and renal toxicity (Yam \& Kwok; Kwok, 2006; Fragasso et al., 2009; Chaanine et al., 2015). Despite of these adverse effects of CLQ treatment on specific organs such as eye, heart and kidney, there are some studies suggested that CLQ treatment improves liver functions in an experimental rat model of hepatocellular carcinoma induced by thioacetamide and attenuates hypoxia-induced pulmonary hypertension (Wu et al., 2017; Helmy et al., 2018). Our study showed that Chloroquine treatment clearly inhibited the histopathological damage caused by Adriamycin in the testicular tissue and ameliorated the decrease in serum testosterone levels. However, taking into account the destructive effects of CLQ on other organs such as the eyes, heart and kidney, further studies should also be performed in these organs to use CLQ as a protective agent against testicular toxicity induced by Adriamycin.

\section{CONCLUSION}

In conclusion, we suggest that Chloroquine can be used as a protective agent at low doses for reducing the negative effects of Adriamycin because of its antiinflammatory properties. Furthermore, we think that the results of this study will contribute to the determination of new strategies in Adriamycin-induced testicular damage and to studies on reducing the negative effects of Adriamycin in healthy tissues and organs. 
AKIN, A. T.; KAYMAK, E.; ÖZTÜRK, E.; KARABULUT, D. \& TOLUK, A. La cloroquina mejora el daño testicular inducido por la adriamicina al suprimir la inflamación y la apoptosis en ratas: Un estudio histológico, inmunohistoquímico y bioquímico. Int. J. Morphol.,39(4):1123-1131, 2021.

RESUMEN: La adriamicina (ADR) es un antibiótico de antraciclina que se usa para el tratamiento de muchos tipos de cáncer. Sin embargo, sus aplicaciones pueden dañar los tejidos sanos. La cloroquina (CLQ) es un agente antiinflamatorio que se utiliza en el tratamiento de enfermedades asociadas a la inflamación, tal como la malaria y la artritis reumatoide. También se utiliza en el tratamiento de la neumonía causada por COVID-19. El objetivo de este estudio fue determinar los posibles efectos terapéuticos de la cloroquina sobre la toxicidad testicular inducida por adriamicina en ratas. Investigamos el efecto de CLQ sobre la lesión testicular causada por ADR. Las ratas se dividieron en cuatro grupos: Control, ADR, CLQ, ADR + CLQ. Después de las administraciones, se sacrificaron los animales y se extrajeron los testículos de los animales para los exámenes adicionales. Se evaluaron los cambios histopatológicos en los tejidos testiculares y se realizó la inmunotinción de TNF- $\alpha$ e IL-6 para determinar los niveles de expresión de estas citocinas. Se utilizó el método TUNEL para la evaluación del índice apoptótico. Además, los niveles de testosterona en suero se midieron mediante un ensayo ELISA. El grupo ADR mostró un deterioro histopatológico en comparación con el grupo Control y observamos que el tratamiento con CLQ mejoró el daño inducido por Adriamicina. Un aumento en las inmunorreactividades de TNF- $\alpha$ e IL-6 y en el número de células apoptóticas además de una disminución en los niveles séricos de testosterona se determinaron en el grupo de ADR en comparación con el grupo de control y CLQ. Además, nuestros exámenes mostraron una mejora en el tejido testicular en el grupo ADR + CLQ en términos de estos parámetros en comparación con el grupo ADR. Sugerimos que CLQ se puede utilizar como agente protector para reducir los efectos tóxicos de la Adriamicina, gracias a sus propiedades antiinflamatorias y antiapoptóticas.

PALABRAS CLAVE: Quimioterapia; Daño de testículo; TUNEL; IL-6; TNF- $\alpha$.

\section{REFERENCES}

Ahmed, F.; Urooj, A.; Karim, A. A. Protective effects of Ficus racemosa stem bark against doxorubucin-induced renal and testicular toxicity. Pharmacogn. Mag., 9(34):130-4, 2013.

Bayatli, F.; Akkus, D.; Kilic, E.; Saraymen, R. \& Sonmez, M. F. The protective effects of grape seed extract on MDA, AOPP, apoptosis and eNOS expression in testicular torsion: an experimental study. World $J$. Urol., 31(3):615-22, 2013.

Ben-Zvi, I.; Kivity, S.; Langevitz, P. \& Shoenfeld, Y. Hydroxychloroquine: from malaria to autoimmunity. Clin. Rev. Allergy Immunol., 42(2):14553, 2012.

Chaanine, A. H.; Gordon, R. E.; Nonnenmacher, M.; Kohlbrenner, E.; Benard, L. \& Hajjar, R. J. High-dose chloroquine is metabolically cardiotoxic by inducing lysosomes and mitochondria dysfunction in a rat model of pressure overload hypertrophy. Physiol. Rep., 3(7):e12413, 2015.
Elsharkawy, A. M. \& Mann, D. A. Nuclear factor-kB and the hepatic inflammation-fibrosis-cancer axis. Hepatology, 46(2):590-7, 2007.

Fimognari, C.; Sestili, P.; Lenzi, M.; Bucchini, A.; Cantelli-Forti, G. \& Hrelia, P. RNA as a new target for toxic and protective agents. Mutat. Res., 648(1-2):15-22, 2008.

Fouad, A. A.; Refaie, M. M. M. \& Abdelghany, M. I. Naringenin palliates cisplatin and doxorubicin gonadal toxicity in male rats. Toxicol. Mech. Methods, 29(1):67-73, 2019.

Fragasso, G.; Sanvito, F.; Baratto, F.; Martinenghi, S.; Doglioni, C. \& Margonato, A. Cardiotoxicity after low-dose chloroquine antimalarial therapy. Heart Vessels, 24(5):385-7, 2009.

He, Y.; Yang, Z.; Li, J. \& Li, E. Dexmedetomidine reduces the inflammation and apoptosis of doxorubicin-induced myocardial cells. Exp. Mol. Pathol., 113:104371, 2020.

Helmy, S. A.; El-Mesery, M.; El-Karef, A.; Eissa, L. A. \& El Gayar, A. M. Chloroquine upregulates TRAIL/TRAILR2 expression and potentiates doxorubicin anti-tumor activity in thioacetamide-induced hepatocellular carcinoma model. Chem. Biol. Interact., 279:84-94, 2018.

Howlader, N.; Krapcho, M.; Miller, D.; Brest, A.; Yu, M.; Ruhl, J.; Tatalovich, Z.; Mariotto, A.; Lewis, D. R.; Chen, H. S.; et al. (Eds.). SEER Cancer Statistics Review, 1975-2016. Bethesda, National Cancer Institute, 2019. Available from: https://seer.cancer.gov/csr/1975_2016/

Huang, M.; Tang, T.; Pang, P.; Li, M.; Ma, R.; Lu, J.; Shu, J.; You, Y.; Chen, B.; Liang, J.; et al. Treating COVID-19 with chloroquine. $J$. Mol. Cell Biol., 12(4):322-5, 2020.

Imahie, H.; Adachi, T.; Nakagawa, Y.; Nagasaki, T.; Yamamura, T. \& Hori, M. Effects of adriamycin, an anticancer drug showing testicular toxicity, on fertility in male rats. J. Toxicol. Sci., 20(3):183-93, 1995.

Johnsen, S. G. Testicular biopsy score count--a method for registration of spermatogenesis in human testes: normal values and results in 335 hypogonadal males. Hormones, 1(1):2-25, 1970.

Lalloo, D. G.; Shingadia, D.; Pasvol, G.; Chiodini, P. L.; Whitty, C. J.; Beeching, N. J.; Hill, D. R.; Warrell, D. A.; Bannister, B. A. \& HPA Advisory Committee on Malaria Prevention in UK Travellers. UK malaria treatment guidelines. J. Infect., 54(2):111-21, 2007.

Lampe, H.; Horwich, A.; Norman, A.; Nicholls, J. \& Dearnaley, D. P. Fertility after chemotherapy for testicular germ cell cancers. J. Clin. Oncol., 15(1):239-45, 1997.

Lehmann, G. L.; Carreras, F. I.; Soria, L. R.; Gradilone, S. A. \& Marinelli, R. A. LPS induces the TNF-alpha-mediated downregulation of rat liver aquaporin-8: role in sepsis-associated cholestasis. Am. J. Physiol. Gastrointest. Liver Physiol., 294(2):G567-75, 2008.

Long, L.; Yang, X.; Southwood, M.; Lu, J.; Marciniak, S. J.; Dunmore, B. J. \& Morrell, N. W. Chloroquine prevents progression of experimental pulmonary hypertension via inhibition of autophagy and lysosomal bone morphogenetic protein type II receptor degradation. Circ. Res., 112(8):1159-70, 2013.

Ma, X.; Zhang, Y.; Zhu, D.; Chen, Z.; Xu, M.; He, L.; Shi, T.; Huang, L. \& Zou, J. Low dosage chloroquine protects retinal ganglion cells against glutamate-induced cell death. Exp. Eye Res., 181:285-93, 2019.

Malekinejad, H.; Janbaz-Acyabar, H.; Razi, M. \& Varasteh, S. Preventive and protective effects of silymarin on doxorubicin-induced testicular damages correlate with changes in c-myc gene expression. Phytomedicine, 19(12):1077-84, 2012.

Noronha, I. L.; Niemir, Z.; Stein, H. \& Waldherr, R. Cytokines and growth factors in renal disease. Nephrol. Dial. Transplant., 10(6):775-86, 1995.

Patel, A. G. \& Kaufmann, S. H. How does doxorubicin work? eLife, 1:e00387, 2012.

Rainsford, K. D.; Parke, A. L.; Clifford-Rashotte, M. \& Kean, W. F. Therapy and pharmacological properties of hydroxychloroquine and chloroquine in treatment of systemic lupus erythematosus, rheumatoid arthritis and related diseases. Inflammopharmacology, 23(5):231-69, 2015.

Rizk, S. M.; Zaki, H. F. \& Mina, M. A. Propolis attenuates doxorubicininduced testicular toxicity in rats. Food Chem. Toxicol., 67:176-86, 2014. 
AKIN, A. T.; KAYMAK, E.; ÖZTÜRK, E.; KARABULUT, D. \& TOLUK, A. Chloroquine ameliorates adriamycin-induced testicular damage by suppressing the inflammation and apoptosis in rats: A histological, immunohistochemical and biochemical study. Int. J. Morphol., 39(4):1123-1131, 2021

Ryter, S. W.; Kim, H. P.; Hoetzel, A.; Park, J. W.; Nakahira, K.; Wang, X. \& Choi, A. M. K. Mechanisms of cell death in oxidative stress. Antioxid. Redox Signal., 9(1):49-89, 2007.

Shivakumar, P.; Rani, M. U.; Reddy, A. G. \& Anjaneyulu, Y. A study on the toxic effects of Doxorubicin on the histology of certain organs. Toxicol. Int., 19(3):241-4, 2012.

Turedi, S.; Yulug, E.; Alver, A.; Kutlu, O. \& Kahraman, C. Effects of resveratrol on doxorubicin induced testicular damage in rats. Exp. Toxicol. Pathol., 67(3):229-35, 2015.

Wang, B.; Guo, H.; Ling, L.; Ji, J.; Niu, J. \& Gu, Y. The chronic adverse effect of chloroquine on kidney in rats through an autophagy dependent and independent pathways. Nephron, 144(2):96-108, 2020.

Wu, K.; Zhang, Q.; Wu, X.; Lu, W.; Tang, H.; Liang, Z.; Gu, Y.; Song, S.; Ayon, R. J.; Wang, Z.; et al. Chloroquine is a potent pulmonary vasodilator that attenuates hypoxia-induced pulmonary hypertension. Br. J. Pharmacol., 174(22):4155-72, 2017.

Xiao, J.; Sun, G. B.; Sun, B.; Wu, Y.; He, L.; Wang, X.; Chen, R. C.; Cao, L.; Ren, X. Y. \& Sun, X. B. Kaempferol protects against doxorubicininduced cardiotoxicity in vivo and in vitro. Toxicology, 292(1):53-62, 2012.

Yam, J. C. \& Kwok, A. K. Ocular toxicity of hydroxychloroquine. Hong Kong Med. J., 12(4):294-304, 2006

Yamagiwa, Y.; Takei, Y.; Koizumi, H.; Nemoto, S.; Kurata, M. \& Satoh, H. Pathological features of corneal phospholipidosis in juvenile white rabbits induced by ocular instillation of chloroquine or amiodarone. Toxicol. Pathol., 47(1):26-34, 2019.

Yang, M.; Cao, L.; Xie, M.; Yu, Y.; Kang, R.; Yang, L.; Zhao, M. \& Tang, D. Chloroquine inhibits HMGB1 inflammatory signaling and protects mice from lethal sepsis. Biochem. Pharmacol., 86(3):410-8, 2013.

Yeh, Y. C.; Liu, T. J.; Wang, L. C.; Lee, H. W.; Ting, C. T.; Lee, W. L.; Hung, C. J.; Wang, K. Y.; Lai, H. C. \& Lai, H. C. A standardized extract of Ginkgo biloba suppresses doxorubicin-induced oxidative stress and p53-mediated mitochondrial apoptosis in rat testes. Br. J. Pharmacol., 156(1):48-61, 2009.

Zhang, S.; You, Z. Q.; Yang, L.; Li, L. L.; Wu, Y. P.; Gu, L. Q. \& Xin, Y. F. Protective effect of Shenmai injection on doxorubicin-induced cardiotoxicity via regulation of inflammatory mediators. $B M C$ Complement. Altern. Med., 19(1):317, 2019.

\section{Corresponding author: \\ Ali Tugrul Akin \\ Erciyes University \\ Science Faculty \\ Department of Biology \\ Kayseri \\ TURKEY}

E-mail: Tugrul.akinn@gmail.com

ORCID ID: 0000-0002-1408-8571

Received: 02-01-2021

Accepted: 03-05-2021 